\title{
Thermotherapy via Humid Heat for the Treatment of Safflower Seeds
}

\author{
Janine Farias Menegaes ${ }^{1}$, Ubirajara Russi Nunes ${ }^{2}$, Rogério Antônio Bellé2, Sidinei José Lopes ${ }^{2}$, \\ Tiéle Stuker Fernandes ${ }^{1}$, Eduardo José Ludwig ${ }^{1}$, Priscila Barbieri Zini ${ }^{1} \&$ Geovana Facco Barbieri ${ }^{3}$ \\ ${ }^{1}$ Postgraduate Program in Agronomy, Federal University of Santa Maria, Santa Maria, Brazil \\ ${ }^{2}$ Department of Crop Science, Federal University of Santa Maria, Santa Maria, Brazil \\ ${ }^{3}$ Graduation in Agronomy, Federal University of Santa Maria, Santa Maria, Brazil \\ Correspondence: Janine Farias Menegaes, Postgraduate Program in Agronomy, Federal University of Santa \\ Maria, Avenida Roraima, ${ }^{\circ}$ 1000, Bairro Camobi, CEP: 97105-900, Santa Maria, RS, Brazil. Tel: \\ 55-991-487-031. E-mail: janine_rs@hotmail.com
}

$\begin{array}{lcc}\text { Received: April 2, } 2019 & \text { Accepted: May 7, } 2019 & \text { Online Published: July 31, } 2019 \\ \text { doi:10.5539/jas.v11n11p30 } & \text { URL: https://doi.org/10.5539/jas.v11n11p30 }\end{array}$

\begin{abstract}
The objectives of this work were to evaluate and adequate the method of thermotherapy via humid heat for the treatment of safflower seeds (Carthamus tinctorius L.) and, to verify its effect on the physiological and sanitary quality of seeds. The experiment was performed in the period from September to November, 2016 and from May to July, 2017, in entirely randomized design, arranged in $5 \times 6+1$ factorial scheme, with five temperatures: 25,35 , 45,55 and $65^{\circ} \mathrm{C}$ and with six time periods: $5,10,15,30,45$ and $60 \mathrm{~min}$, plus the additional treatment (control), with eight repetitions. The seeds were packaged in glass of $500 \mathrm{~mL}$ and disposed in thermodigital water bath device with heated water according to the abovementioned factorial. We evaluated the degree of humidity of the seeds after thermotherapic treatments, the germination of normal seedlings, the emergence at field, the speed indexes of germination and emergence, the length and dry mass of seedlings and the sanity test. We observed that the treatment of seeds via humid heat thermotherapy was efficient in the control of phytopathogens, without damage to the physiological quality until $45^{\circ} \mathrm{C}$. The treatment of $45^{\circ} \mathrm{C}$ for $15 \mathrm{~min}$ provided the greater reduction of the pathogens on the safflower seeds, incrementing its germinative potential and emergence at field.
\end{abstract}

Keywords: Carthamus tinctorius L., physiological quality, sanity, ornamental seeds

\section{Introduction}

The safflower (Carthamus tinctorius L.), Asteraceae, is a species of economic concern with broad fitness for use, from food to ornamental, offering high variability of raw materials. As ornamental plant, we highlight the inflorescences by the beauty, rusticity and versatility of the use form, such as, fresh and/or dry cut flower (Abud et al., 2010; Emongor \& Oagile, 2017).

The safflower seeds have high oil content, on average of $35 \%$, which is extracted and used, as raw material in the food, pharmaceutical and oil industry, with cultivation for this purpose in more than 60 countries, highlighting China, United States, Mexico and Argentina. In Brazil, the cultivation of safflower is still incipient both to production of seeds and cut flowers (Faostat, 2017).

The phytosanitary quality of ornamental seeds, mainly, the safflower ones contributes positively for the formation of the plants stand and consequently, for a production of quality of their floral stems, as well as the production of seeds. This way, the treatment of seeds is indispensable to avoid the dissemination of field diseases. Among the treatment techniques of seeds, the thermotherapy via humid heat or hot water immersion becomes a viable alternative and with low environmental impact (Silva et al., 2002; Lazarotto et al., 2013).

The thermotherapy, which uses the temperature-time binomial, as seeds means of treatment, must be adjusted to each species, in a way that it does not affect negatively the physiological quality, for example, the germination. Once that, the thermotherapic method via humid heat presents greater thermal capacity, and this requires a shorter time of exposure of seeds, to avoid the early rupture of the tegument and, consequently, the soaking in heated water, in order to mitigate the damage and the exacerbated leakage of the substances via membrane (Machado, 2000; Coutinho et al., 2007). 
The thermotherapy for the control of phytopathogens has been showed itself efficient for several species, such as: squash (Cucurbita pepo L.) (Cunha et al., 2017), alfalfa (Medicago sativa L.) (Mendes et al., 2001), brachiaria (Brachiaria brizantha Hochst.) (Marchi et al., 2008), Spondias mombin (Spondias mombin L.) (Brito et al., 2008), canafistula (Peltophorum dubium Spreng.) (Lazarotto et al., 2013), cumaru (Amburana cearensis A.C. Smith) (Oliveira et al., 2011), beans (Phaseolus vulgaris L.) (Estefani, Miranda Filho, \& Uesugi, 2007), castor oil plant (Ricinus communis L.) (Marroni et al., 2009), passion fruit (Passiflora suberosa L.) (Marostega et al., 2015), maize (Zea mays L.) (Coutinho et al., 2007), tomato (Solanum lycopersicum L.) Carmo et al. (2004) Braga et al. (2010), among others, without damage to the physiological quality, offering an alternative to the use of chemical products, commonly used in the seeds treatment. Oliveira et al. (2011) highlight that this form of seeds treatment is viable for the pathogens control, without environmental damage, because it does not use pollutants and it does not emit residues.

Thus, the objectives of this work were to evaluate and adequate the method of thermotherapy via humid heat for the treatment of safflower seeds and, to verify its effect on the physiological and sanitary quality of seeds.

\section{Material and Methods}

The experiment was carried out in the period from September to November, 2016, and from May to July, 2017, in the Seed Research and Teaching Laboratory (LDPS) of the Department of Plant Science in the Federal University of Santa Maria (UFSM), RS (29 $43^{\prime} \mathrm{S} ; 53^{\circ} 43^{\prime} \mathrm{W}$ and altitude of $\left.95 \mathrm{~m}\right)$. The safflower seeds used are from Yellow Saffron cultivar, collected in the crop of 2015/2016, the seeds were stored in cold chamber $\left(15{ }^{\circ} \mathrm{C}\right.$ and $40 \% \mathrm{UR}$ ) in kraft paper bags (brown paper type of $1 \mathrm{~kg}$ ), with average degree of humidity of $9 \%$.

The experiment of thermotherapy via humid heat was in entirely randomized treatment, arranged in $5 \times 6+1$ factorial scheme, with five temperatures: $25,35,45,55$ and $65^{\circ} \mathrm{C}$ and with six time periods: $5,10,15,30,45$ and $60 \mathrm{~min}$, plus the additional treatment (control), with eight repetitions. The seeds were packed in glass (Becker) of $500 \mathrm{~mL}$ having distilled water and disposed in thermodigital water bath device with heated water in the temperatures and time according to the abovementioned factorial. Previously, the seeds were soaked in distilled water that was not heated, during one hour, for elimination of air pockets between the superficial dead tissues, facilitating the conduction of heat in the seeds tissues (Coutinho et al., 2007). After the treatment by thermotherapy, the seeds were put to dry on toilet paper at room temperature by the period of $24 \mathrm{~h}$.

In the sequence, we evaluated the physics, physiological and sanitary qualities of these seeds by the following tests:

Humidity degree of seeds after thermotherapic treatment: determined by the greenhouse method $105 \pm 3{ }^{\circ} \mathrm{C}$ for 24 $\mathrm{h}$, using four repetitions of $5 \mathrm{~g}$ (adapted Brasil, 2009a).

Standard test of germination, first count of germination (vigor) and speed index of germination (IVG): sown eight repetitions of 50 seeds, in paper roll of germination, moistened with distilled water in proportion of 2.5 times the mass of the dry paper. The rolls were kept in BOD (Box Organism Development) type germinators, with photoperiod of $24 \mathrm{~h}$ and temperature of $25 \pm 2{ }^{\circ} \mathrm{C}$. The evaluations of vigor and germination were at four and 14 DAS (days after sowing), respectively (Brasil, 2009a). The IVG with daily evaluations according to methodology described by Maguire (1962), adapted for the culture of safflower used as criteria the elongation of the primary root and emergence of the cotyledons (Abud et al., 2010).

Length and dry mass of seedling: performed with eight repetitions of 20 seeds, sowed in two non-matching lines in the upper third of the germination paper and, maintained in the same condition of the standard test of germination. At the four DAS the length of the aerial and root parts of ten normal seedlings of each repetition were measured. In the sequence, we determined the total dry mass by drying of the material in forced ventilation oven at $65 \pm 5^{\circ} \mathrm{C}$ by $48 \mathrm{~h}$ (Nakagawa, 1999).

Emergence at field and emergence speed index (IVE): eight repetitions of 50 seeds were sown in lines of $1 \mathrm{~m}$, with spacing between them of $0.2 \mathrm{~m}$ and in grooves of $0.03 \mathrm{~m}$ of depth. The IVE was determined with daily evaluations according to the methodology described by Maguire (1962), adapted for the safflower culture using as criteria the development of the cotyledons and epicotyls, and the evaluation of emergence was performed at 14 DAS (Abud et al., 2010).

For the germination variables of normal seedlings and emergence at field, we used as pattern the Normative Instruction n.45/2013 of MAPA (Ministy of Agriculture, Livestock and Supply) (Brasil, 2013). This normative regulates the standards of production and commercialization of seeds in Brazil; however, the same does not contemplate the safflower seeds, thus, we chose the standard of sunflower seeds (Helianthus annuus L.) because 
it belongs to the same botanical family of safflower, Asteraceae, and it is demanded between $65-70 \%$ of germination (Brasil, 2013).

Sanity test in filter-paper: performed through the incubation in paper substrate (Blotter Test), with eight repetitions of 50 seeds. The sowing occurred in plastic transparent boxes for germination (gerbox), prepared with three sheets of paper of germination moistened with distilled water corresponding to 2.5 times the mass of dry paper. The germination was inhibited by the method of freezing for $24 \mathrm{~h}$. Subsequently, the seeds remained in BOD for five days with photoperiod of $12 \mathrm{~h}$ of light and temperature of $20 \pm 2{ }^{\circ} \mathrm{C}$. They were evaluated in magnifying glass (stereo microscope) the percentage of seeds infested and the identification of the phytopathogens at level of genus (Brasil, 2009b).

The data expressed in percentage was transformed in arc-sine $\sqrt{\% / 100}$. The analysis of variance of data was performed with the help of SISVAR program (Ferreira, 2014), at level of 5\% of error. We used the contrast test of the additional treatment (control) versus the factorial (levels of temperature and periods of time) and, also, the comparison of averages of the factorial by the Scott-Knott test. The Pearson correlation, at level of significance of $5 \%$, was performed among the total infested seeds and the first count, germination, emergence of dead seedlings and seeds in the germination test.

\section{Results and Discussion}

The physical, physiological and sanitary quality of safflower seeds was measured by the analysis of the variables by the contrast test of the additional treatment (control) with the thermotherapic factorial (levels of temperature and periods of time), which were significant at $5 \%$ of error, as well as the interaction between the levels of temperature and the periods of time. In general, the control treatment presented superior average to the combinations of temperature and time, except for the variable degree of humidity, which presented negative estimate and non-significance in the factorial (Table 1). 
Table 1. Estimate of the contrast between the control and the combinations of temperature and time, and the comparisons of averages of the combinations for humidity degree of seeds, first count, germination of normal seedlings, emergence at field and total infested seeds of $C$. tinctorius submitted to thermotherapy via humid heat

\begin{tabular}{|c|c|c|c|c|c|c|c|c|c|}
\hline \multirow{3}{*}{\multicolumn{2}{|c|}{ Additional Treatment }} & \multicolumn{8}{|c|}{ Factorial } \\
\hline & & \multirow{2}{*}{$\begin{array}{l}\text { Temperature } \\
\left({ }^{\circ} \mathrm{C}\right)\end{array}$} & \multicolumn{7}{|c|}{ Periods of time (minutes) } \\
\hline & & & 5 & 10 & 15 & 30 & 45 & 60 & Media \\
\hline \multicolumn{10}{|c|}{ Humidity degree (\%) } \\
\hline Control & 8.5 & 25 & $10.1^{\mathrm{ns}}$ & 10.0 & 10.4 & 11.1 & 11.6 & 11.4 & $10.8 \mathrm{c}$ \\
\hline \multirow[t]{4}{*}{ Estimate $^{\mathrm{A}}$} & $-92 *$ & 35 & 10.3 & 10.2 & 10.6 & 11.3 & 11.8 & 11.7 & $11.0 \mathrm{c}$ \\
\hline & & 45 & 10.6 & 10.5 & 10.9 & 11.6 & 12.2 & 12.0 & $11.3 \mathrm{~b}$ \\
\hline & & 55 & 11.1 & 11.0 & 11.4 & 12.2 & 12.8 & 12.6 & $11.8 \mathrm{~b}$ \\
\hline & & 65 & 11.7 & 11.6 & 12.0 & 12.8 & 13.4 & 13.3 & $12.5 \mathrm{a}$ \\
\hline $\mathrm{CV}(\%)$ & 5.62 & Average & $10.7 \mathrm{C}$ & $10.7 \mathrm{C}$ & $11.0 \mathrm{C}$ & $11.8 \mathrm{~B}$ & $12.4 \mathrm{~A}$ & $10.7 \mathrm{C}$ & \\
\hline \multicolumn{10}{|c|}{ First count of germination (\%) } \\
\hline Control & 39 & 25 & $41 \mathrm{Aa} * *$ & $40 \mathrm{Aa}$ & $40 \mathrm{Aa}$ & $37 \mathrm{Ab}$ & $36 \mathrm{Ac}$ & $35 \mathrm{Ac}$ & 38 \\
\hline \multirow[t]{4}{*}{ Estimate ${ }^{\mathrm{A}}$} & $525 *$ & 35 & $39 \mathrm{Ba}$ & $39 \mathrm{Aa}$ & $40 \mathrm{Aa}$ & $32 \mathrm{Bc}$ & $36 \mathrm{Ab}$ & $36 \mathrm{Ab}$ & 37 \\
\hline & & 45 & $41 \mathrm{Aa}$ & $40 \mathrm{Aa}$ & $40 \mathrm{Aa}$ & $30 \mathrm{Bb}$ & $24 \mathrm{Bc}$ & $22 \mathrm{Bc}$ & 33 \\
\hline & & 55 & $10 \mathrm{Da}$ & $10 \mathrm{Ba}$ & $10 \mathrm{Ba}$ & $7 \mathrm{Ca}$ & $0 \mathrm{Cb}$ & $0 \mathrm{Cb}$ & 6 \\
\hline & & 65 & $0 \mathrm{Ea}$ & $0 \mathrm{Ca}$ & $0 \mathrm{Ca}$ & $0 \mathrm{Da}$ & $0 \mathrm{Ca}$ & $0 \mathrm{Ca}$ & 0 \\
\hline $\mathrm{CV}(\%)$ & 9.45 & Average & 26 & 26 & 26 & 21 & 19 & 26 & \\
\hline \multicolumn{10}{|c|}{ Germination of normal seedlings (\%) } \\
\hline Control & 66 & 25 & $70 \mathrm{Aa} * *$ & $70 \mathrm{Aa}$ & $70 \mathrm{Ba}$ & $70 \mathrm{Aa}$ & $69 \mathrm{Aa}$ & $68 \mathrm{Aa}$ & 69 \\
\hline \multirow[t]{4}{*}{ Estimate ${ }^{\mathrm{A}}$} & $785 *$ & 35 & $63 \mathrm{Ba}$ & $65 \mathrm{Ba}$ & $71 \mathrm{Ba}$ & $52 \mathrm{Cc}$ & $36 \mathrm{Cd}$ & $32 \mathrm{Cd}$ & 53 \\
\hline & & 45 & $73 \mathrm{Aa}$ & $73 \mathrm{Aa}$ & $75 \mathrm{Aa}$ & $63 \mathrm{Bb}$ & $58 \mathrm{Bc}$ & $54 \mathrm{~B} \mathrm{c}$ & 66 \\
\hline & & 55 & $19 \mathrm{Ca}$ & $19 \mathrm{Ca}$ & $20 \mathrm{Ca}$ & $14 \mathrm{Db}$ & $0 \mathrm{Dc}$ & $0 \mathrm{Dc}$ & 12 \\
\hline & & 65 & $0 \mathrm{Da}$ & $0 \mathrm{Da}$ & $0 \mathrm{Da}$ & $0 \mathrm{Ea}$ & $0 \mathrm{Da}$ & $0 \mathrm{Da}$ & 0 \\
\hline $\mathrm{CV}(\%)$ & 8.65 & Average & 45 & 45 & 47 & 40 & 33 & 45 & \\
\hline \multicolumn{10}{|c|}{ Emergence at field (\%) } \\
\hline Control & 76 & 25 & $80 \mathrm{Aa} * *$ & $81 \mathrm{Aa}$ & $79 \mathrm{Bb}$ & $76 \mathrm{Ab}$ & $74 \mathrm{Ab}$ & $70 \mathrm{Ab}$ & 77 \\
\hline \multirow[t]{4}{*}{ Estimate ${ }^{\mathrm{A}}$} & $741^{*}$ & 35 & $73 \mathrm{Ba}$ & $73 \mathrm{Ba}$ & $72 \mathrm{Ca}$ & $69 \mathrm{Bb}$ & $68 \mathrm{Bb}$ & $64 \mathrm{Bb}$ & 70 \\
\hline & & 45 & $80 \mathrm{Aa}$ & $81 \mathrm{Aa}$ & $83 \mathrm{Aa}$ & $76 \mathrm{Ab}$ & $68 \mathrm{Bc}$ & $66 \mathrm{Bc}$ & 75 \\
\hline & & 55 & $66 \mathrm{Ca}$ & $58 \mathrm{Cb}$ & $46 \mathrm{Dc}$ & $43 \mathrm{Cc}$ & $0 \mathrm{Cd}$ & $0 \mathrm{Cd}$ & 35 \\
\hline & & 65 & $0 \mathrm{Da}$ & $0 \mathrm{Da}$ & $0 \mathrm{Ea}$ & $0 \mathrm{Da}$ & $0 \mathrm{Ca}$ & $0 \mathrm{Ca}$ & 0 \\
\hline $\mathrm{CV}(\%)$ & 6.86 & Average & 60 & 59 & 56 & 53 & 42 & 60 & \\
\hline \multicolumn{10}{|c|}{ Total infested seeds (\%) } \\
\hline Control & 42 & 25 & $9 \mathrm{Dc} * *$ & $17 \mathrm{~Eb}$ & $17 \mathrm{Cb}$ & $13 \mathrm{Cb}$ & $16 \mathrm{Db}$ & $22 \mathrm{Ba}$ & 15 \\
\hline \multirow[t]{4}{*}{ Estimate ${ }^{\mathrm{A}}$} & $637 *$ & 35 & $22 \mathrm{Ba}$ & $20 \mathrm{Ca}$ & $18 \mathrm{Cb}$ & $13 \mathrm{Cc}$ & $12 \mathrm{Dc}$ & $20 \mathrm{Ca}$ & 18 \\
\hline & & 45 & $24 \mathrm{Aa}$ & $26 \mathrm{Aa}$ & $27 \mathrm{Aa}$ & $26 \mathrm{Aa}$ & $25 \mathrm{Bb}$ & $19 \mathrm{Cc}$ & 24 \\
\hline & & 55 & $27 \mathrm{Aa}$ & $22 \mathrm{Bb}$ & $19 \mathrm{Cc}$ & $24 \mathrm{Ab}$ & $20 \mathrm{Cc}$ & $17 \mathrm{Dd}$ & 21 \\
\hline & & 65 & $19 \mathrm{Cb}$ & $23 \mathrm{Bb}$ & $23 \mathrm{Bb}$ & $20 \mathrm{Bb}$ & $33 \mathrm{Aa}$ & $35 \mathrm{Aa}$ & 25 \\
\hline $\mathrm{CV}(\%)$ & 24.59 & Average & 20 & 22 & 20 & 19 & 21 & 20 & \\
\hline
\end{tabular}

Note. * Significant effect by the contrast test of additional treatment (control) versus the factorial (levels of temperature x periods of time), at level of $5 \%$ of error. ${ }^{A}$ Estimate of contrast by coefficients $(+30,-1,-1,-1,-1$, $-1,-1,-1,-1,-1,-1,-1,-1,-1,-1,-1,-1,-1,-1,-1,-1,-1,-1,-1,-1,-1,-1,-1,-1,-1$ and -1) (Ferreira, 2014). ** Averages are not followed by the same letter, upper case in the column and lower case in the line, differ Scott-Knott test at level of 5\% of error. CV(\%): coefficient of variation.

Initially, the safflower seed lot presented $8.5 \%$ of humidity degree (without thermotherapy). We observed that the increase of the humidity degree of the safflower seeds after the thermotherapic treatments was according to the period of exposure of the same in heated water; however, with values that vary from 10.0 to $13.4 \%$ in relation to the tested temperatures (Table 1). This variation in the humidity degree of seeds is in virtue of the previous soaking and the period of exposure to this treatment method. Corroborating the results obtained in this work, Braga et al. (2010) also, verified an increase in the percentage of the humidity degree in the tomato seeds after the thermotherapic treatments via humid heat. 
For the seed preservation, Coutinho et al. (2007) indicated the necessity of soaking the seeds in non-heated distilled water with the intention of eliminating the air pockets between the superficial dead tissues, facilitating the heat conduction in the seed tissues and avoiding greater damage to the membranes. Marcos-Filho (2015) reports that the maintenance of the membrane system integrity is fundamental for the vitality preservation and viability of seeds.

In relation to the seed vigor obtained by the germination first count, at four DAS (days after sowing), we observed that in temperatures of $25 ; 35$ and $45^{\circ} \mathrm{C}$ when the same were exposed to $5 ; 10$ and 15 min of humid heat, in a general way, the vigor was similar to the additional treatment (without thermotherapy). We verified that the most accentuated reduction of the safflower seed vigor occurred in the exposure to temperatures superior to $45^{\circ} \mathrm{C}$ and for more than 30 min of soaking in heated water. Marcos-Filho (2015) reports that the initial seed hydration in form of water vapor, when in high temperatures, can cause damage to the membranes by leaching of cellular content, resulting in the increase of the speed deterioration and in reduction of germinative potential.

The initial physiological quality of the safflower seed lot used, in this work, was of $66 \%$ of germination of normal seedlings and $76 \%$ of emergence at field, characterizing itself as a commercial lot according to the standards of MAPA (Brasil, 2013). The evaluation of germination was performed at 14 DAS, in which, we verified that the standard demanded by MAPA maintains itself in the temperature of $25{ }^{\circ} \mathrm{C}$ in all the tested periods of time, obtaining the same performance for the emergence at field. Yet, in the temperatures of 35 and 45 ${ }^{\circ} \mathrm{C}$ the germination standard remains until the period of $15 \mathrm{~min}$ of exposure in heated water.

Among the thermotherapic treatments, we verified that the treatment of $45^{\circ} \mathrm{C}$ for $15 \mathrm{~min}$ stood out from the others, resulting in $75 \%$ of germination of normal seedlings in laboratory and $83 \%$ of emergence at field. Oliveira et al. (2011) verified that according to the increase of the exposure period of cumaru seeds to humid heat $\left(60^{\circ} \mathrm{C}\right.$ for 5,10 and $\left.20 \mathrm{~min}\right)$ there was a greater expression of both the vigor and the germination potential, as it was verified in the treatment of $45^{\circ} \mathrm{C} 15 \mathrm{~min}^{-1}$ for the safflower seeds.

The germination of the seeds and their emergence in the field depend directly on the favorable environmental conditions to which they were submitted. Acting directly in metabolic processes related to them, since the hydrolysis of their reserves to biosynthesis of new tissues (Marcos-Filho, 2015). For the safflower seeds, we observed that the thermal capacity to maintain the metabolic processes is at $45^{\circ} \mathrm{C}$, favoring the expression of germinability.

However, Coutinho et al. (2007) verified that the vigor loss and the germinative potential loss of the maize seeds treated by thermotherapy via humid heat was increasing according to the exposure period of seeds to this treatment, being the vigor and germination close to zero in the most stringent treatment $\left(60^{\circ} \mathrm{C}, 20 \mathrm{~min}^{-1}\right)$. These results corroborate with the ones obtained in the present work, because in the most stringent treatment of $65^{\circ} \mathrm{C}$ $60 \mathrm{~min}^{-1}$ affected the physiological quality of the seeds, inhibiting totally the germination (Table 1).

The physiological quality of the safflower seeds measured by the emergence test at field verified that in these conditions the emergence supports greater thermal amplitude, obtaining emergence values until $55^{\circ} \mathrm{C} 30 \mathrm{~min}^{-1}$ (Table 1). Thus, the emergence test at field enables to the safflower seeds treated by thermotherapy an improvement in the production potential expression of seedlings in relation to the germination standard test. This improvement can be explained by the interaction of the environment (conditions not controlled), substrate (soil) and to the phytopathogens incident in the seeds, because in the germination standard test there is a constancy in the environmental conditions, which provides the pressure of the inoculum on the seeds and substrate (germination paper).

We verified that the safflower seeds presented high incidence of phytopathogens with $42 \%$ of total infested seeds in the sanity test (Table 1). Nevertheless, we observed a significant reduction in the infestation of phytopathogens in the seeds according to the thermotherapic treatments, in which the increase of the period of exposure of the same in heated water soaking was beneficial to this reduction, being similar among the tested temperatures. Coutinho et al. (2007) using thermotherapic treatment via humid heat for phytopathogenic control in maize seeds, concluded that the increase of the exposure period of the seeds in heated water reduces the infestation, corroborating with the results of this work. Braga et al. (2010) highlighted that the success of the thermotherapy depends directly of the satisfactory combination between the control of the phytopathogens incident in the seeds and the minimum maintenance of its physiological quality.

The phytopathogens of greater incidence identified in the safflower seeds were the ones of the genus: Aspergillius spp., Botrytis spp., Fusarium spp., Penicillium spp., and Sclerotinia spp. In the additional treatment (without thermotherapy) the incidence of phytopathogens was of $42 \%$ of total seeds, from this percentage $81 \%$ was of Aspergillius spp. in the same treatment (Table 2). 
Table 2. Contrast between the control and the combinations of temperature and time, and the comparison of averages of the combinations for sanity test in C. tinctorius seeds submitted to thermotherapy via humid heat

\begin{tabular}{|c|c|c|c|c|c|c|c|c|}
\hline \multirow{3}{*}{\multicolumn{2}{|c|}{ Additional Treatment }} & \multicolumn{7}{|c|}{ Factorial } \\
\hline & & \multirow{2}{*}{$\begin{array}{l}\text { Temperature } \\
\left({ }^{\circ} \mathrm{C}\right)\end{array}$} & \multicolumn{6}{|c|}{ Periods of time (minutes) } \\
\hline & & & 5 & 10 & 15 & 30 & 45 & 60 \\
\hline \multicolumn{9}{|c|}{ Aspergillius spp. (\%) } \\
\hline Control & 81 & 25 & $0 \mathrm{Bb}^{* *}$ & $17 \mathrm{Ab}$ & $0 \mathrm{Bb}$ & $14 \mathrm{Ab}$ & $0 \mathrm{Ab}$ & $0 \mathrm{Bb}$ \\
\hline \multirow[t]{3}{*}{ Estimate $^{\mathrm{A}}$} & $1.392 *$ & 35 & $0 \mathrm{Bb}$ & $12 \mathrm{Ab}$ & $0 \mathrm{Bb}$ & $9 \mathrm{Ab}$ & $0 \mathrm{Ab}$ & $0 \mathrm{Bb}$ \\
\hline & & 45 & $0 \mathrm{Bb}$ & $8 \mathrm{Ac}$ & $20 \mathrm{Ab}$ & $0 \mathrm{Bb}$ & $0 \mathrm{Ab}$ & $24 \mathrm{Ab}$ \\
\hline & & 55 & $11 \mathrm{Bb}$ & $8 \mathrm{Ab}$ & $20 \mathrm{Aa}$ & $0 \mathrm{Bc}$ & $0 \mathrm{Ac}$ & $24 \mathrm{Aa}$ \\
\hline $\mathrm{CV}(\%)$ & 73.89 & 65 & $78 \mathrm{Ab}$ & $0 \mathrm{Bc}$ & $19 \mathrm{Ab}$ & $12 \mathrm{Ab}$ & $0 \mathrm{Ac}$ & $0 \mathrm{Bc}$ \\
\hline \multicolumn{9}{|c|}{ Botrytis spp. (\%) } \\
\hline Control & 2 & 25 & $0 \mathrm{Aa}^{* *}$ & $0 \mathrm{Ba}$ & $0 \mathrm{Ba}$ & $0 \mathrm{Ba}$ & $0 \mathrm{Aa}$ & $0 \mathrm{Aa}$ \\
\hline \multirow[t]{3}{*}{ Estimate $^{\mathrm{A}}$} & $-167^{\mathrm{ns}}$ & 35 & $0 \mathrm{Ab}$ & $0 \mathrm{Bb}$ & $14 \mathrm{Aa}$ & $0 \mathrm{Bb}$ & $0 \mathrm{Ab}$ & $0 \mathrm{Ab}$ \\
\hline & & 45 & $0 \mathrm{Ab}$ & $0 \mathrm{Bb}$ & $0 \mathrm{Bb}$ & $7 \mathrm{Aa}$ & $0 \mathrm{Ab}$ & $0 \mathrm{Ab}$ \\
\hline & & 55 & $0 \mathrm{Ab}$ & $0 \mathrm{Bb}$ & $0 \mathrm{Bb}$ & $7 \mathrm{Aa}$ & $0 \mathrm{Ab}$ & $0 \mathrm{Ab}$ \\
\hline $\mathrm{CV}(\%)$ & 82.86 & 65 & $0 \mathrm{Ab}$ & $11 \mathrm{Aa}$ & $13 \mathrm{Aa}$ & $12 \mathrm{Aa}$ & $0 \mathrm{Ab}$ & $0 \mathrm{Ab}$ \\
\hline \multicolumn{9}{|c|}{ Fusarium spp. (\%) } \\
\hline Control & 0 & 25 & $67^{\mathrm{ns}}$ & 17 & 33 & 29 & 50 & 25 \\
\hline \multirow[t]{3}{*}{ Estimate ${ }^{\mathrm{A}}$} & $-800 *$ & 35 & 67 & 38 & 57 & 30 & 50 & 25 \\
\hline & & 45 & 50 & 54 & 20 & 29 & 91 & 18 \\
\hline & & 55 & 78 & 54 & 20 & 29 & 91 & 18 \\
\hline $\mathrm{CV}(\%)$ & 88.15 & 65 & 4 & 39 & 31 & 18 & 70 & 13 \\
\hline \multicolumn{9}{|c|}{ Penicillium spp. (\%) } \\
\hline Control & 5 & 25 & $11^{\mathrm{ns}}$ & 17 & 0 & 0 & 28 & 63 \\
\hline \multirow[t]{3}{*}{ Estimate $^{\mathrm{A}}$} & $-26^{\mathrm{ns}}$ & 35 & 11 & 12 & 0 & 23 & 28 & 63 \\
\hline & & 45 & 50 & 0 & 20 & 29 & 9 & 24 \\
\hline & & 55 & 11 & 0 & 20 & 29 & 9 & 24 \\
\hline $\mathrm{CV}(\%)$ & 32,83 & 65 & 9 & 28 & 19 & 35 & 0 & 13 \\
\hline \multicolumn{9}{|c|}{ Sclerotinia spp. (\%) } \\
\hline Testemunha & 12 & 25 & $22 \mathrm{Ab}^{* *}$ & $50 \mathrm{Aa}$ & $67 \mathrm{Aa}$ & $57 \mathrm{Aa}$ & $22 \mathrm{Ab}$ & $13 \mathrm{Cb}$ \\
\hline \multirow[t]{3}{*}{ Estimativa $^{A}$} & $-400 *$ & 35 & $22 \mathrm{Ab}$ & $37 \mathrm{Ba}$ & $29 \mathrm{Ba}$ & $37 \mathrm{Ba}$ & $22 \mathrm{Ab}$ & $13 \mathrm{Cb}$ \\
\hline & & 45 & $0 \mathrm{Cb}$ & $38 \mathrm{Ba}$ & $40 \mathrm{Aa}$ & $36 \mathrm{Ba}$ & $0 \mathrm{Bb}$ & $35 \mathrm{Ba}$ \\
\hline & & 55 & $0 \mathrm{Cb}$ & $38 \mathrm{Ba}$ & $40 \mathrm{Aa}$ & $36 \mathrm{Ba}$ & $0 \mathrm{Bb}$ & $35 \mathrm{Ba}$ \\
\hline $\mathrm{CV}(\%)$ & 50.32 & 65 & $9 \mathrm{Ba}$ & $22 \mathrm{Ba}$ & $19 \mathrm{Ba}$ & $24 \mathrm{Ba}$ & $30 \mathrm{Aa}$ & $75 \mathrm{Aa}$ \\
\hline
\end{tabular}

Note. ${ }^{*}$ Significant effect and ${ }^{\mathrm{ns}}$ non-significant effect by contrast test of additional treatment (control) versus the factorial (levels of temperature $\mathrm{x}$ periods of time), at level of $5 \%$ of error. ${ }^{\mathrm{A}}$ Estimate of contrast by coefficients $(+30,-1,-1,-1,-1,-1,-1,-1,-1,-1,-1,-1,-1,-1,-1,-1,-1,-1,-1,-1,-1,-1,-1,-1,-1,-1,-1,-1,-1,-1$ and -1$)$ (Ferreira, 2014). ** Averages are not followed by the same letter, uppercase for levels of temperature and lower case for periods of time; differ from Scott-Knott test at level of 5\% of error. CV(\%): coefficient of variation.

Among the phytopathogens incident in the safflower seeds Botrytis spp. was the one that presented the lowest percentages of infestation, however, the thermotherapic treatments were efficient in controlling this pathogen.

The pathogens of Fusarium spp. genus presented high incidence in the thermotherapic treatments except for the additional treatment (without thermotherapy). And, we observed that the thermotherapic treatments were not efficient for controlling this pathogen. The pathogens of Penicillium spp. genus in the additional treatment (without thermotherapy) presented $5 \%$ of percentage on the total of $42 \%$, without statistical difference between the additional and the factorial treatment, as well as, for the factorial analyzed separately. The pathogens of Sclerotinia spp. genus presented high infestation in the thermotherapic treatments with periods of exposure to humid heat of 45 and $60 \mathrm{~min}$.

According to Girardi et al. (2013) working with the quality of safflower seeds collected in different periods of maturation, also, verified high incidence of phytopathogens in this seeds, being Aspergillus spp., Fusarium spp. and Penicillium spp. the most relevant, with percentages of incidence of $62 ; 42$ and 56\%, respectively. Machado 
(2000) mentions that Aspergillus spp. and Penicillium spp. are the phytopathogens that contribute the most for the deterioration of seeds depreciating their physiological quality.

However, Schneider et al. (2015) concluded that the thermal treatments $25 ; 45 ; 50$ and $55^{\circ} \mathrm{C}$ for 15 min were not efficient to the control of the Fusarium spp. pathogens incidents in the oilseeds of jatropha (Jatropha curcas L.), confirming the results of the present work. Lazarotto et al. (2013) verified that the thermotherapic treatments via humid heat $\left(80^{\circ} \mathrm{C}\right.$ for $0 ; 5 ; 10 ; 15$ and $20 \mathrm{~min}$ ) were not efficient to prevent the infestation of phytopathogens on the seeds of cassia fistula without affecting negatively its physiological quality. Nevertheless, Cunha et al. (2017) concluded that the thermotherapy via humid heat at $60{ }^{\circ} \mathrm{C}$ for until 18 min reduces the incidence of phytopathogens in squash seeds without damage in their physiological quality.

The indexes IVG and IVE (index of speed of germination and emergence, respectively) were decreasing according to the increase of temperature and the period of exposure of seeds to humid heat, with values that confirm the vigor, demonstrating viability of germination and emergence until $45^{\circ} \mathrm{C} 30 \mathrm{~min}^{-1}$ (Table 3). This indicates that according to the exposure of the safflower seeds to the humid heat, the trigger of the metabolic processes of the nutritional reservation of these seeds was slower. Marcos-Filho (2015) reports that the deterioration process of seeds depends on the genetic heritage since the rearrange of the membranes for the beginning of the germinative three-phase process, added to the degree of humidity and heat exposure. 
Table 3. Estimate of the contrast between the control and combinations of temperature and time, and comparison of averages of combinations for germination speed index (IVG), emergence velocity index (IVE), length and dry mass of root and aerial parts of seedlings of $C$. tinctorius submitted to thermotherapy via humid heat

\begin{tabular}{|c|c|c|c|c|c|c|c|c|}
\hline \multirow{3}{*}{\multicolumn{2}{|c|}{ Additional Treatment }} & \multicolumn{7}{|c|}{ Factorial } \\
\hline & & \multirow{2}{*}{$\begin{array}{l}\text { Temperature } \\
\left({ }^{\circ} \mathrm{C}\right)\end{array}$} & \multicolumn{6}{|c|}{ Periods of time (minutes) } \\
\hline & & & 5 & 10 & 15 & 30 & 45 & 60 \\
\hline \multicolumn{9}{|l|}{$I V G$} \\
\hline Control & 56.4 & 25 & $41.0 \mathrm{Aa} * *$ & $33.8 \mathrm{Aa}$ & $32.7 \mathrm{Aa}$ & $18.7 \mathrm{Bb}$ & $17.4 \mathrm{Ab}$ & $16.9 \mathrm{Bb}$ \\
\hline \multirow[t]{3}{*}{ Estimate $^{\mathrm{A}}$} & $1.162 *$ & 35 & $21.0 \mathrm{Ca}$ & $19.5 \mathrm{Bb}$ & $1.9 \mathrm{Bb}$ & $23.5 \mathrm{Aa}$ & $21.9 \mathrm{Aa}$ & $21.2 \mathrm{Aa}$ \\
\hline & & 45 & $36.4 \mathrm{Ba}$ & $3.0 \mathrm{Aa}$ & $37.6 \mathrm{Aa}$ & $27.5 \mathrm{Ab}$ & $18.8 \mathrm{Ac}$ & $19.1 \mathrm{Ac}$ \\
\hline & & 55 & $22.0 \mathrm{Ca}$ & $15.1 \mathrm{Bb}$ & $15.3 \mathrm{Bb}$ & $17.6 \mathrm{Bb}$ & $0.0 \mathrm{Bc}$ & $0.0 \mathrm{Cc}$ \\
\hline $\mathrm{CV}(\%)$ & 35.93 & 65 & $0.0 \mathrm{a}$ & $0.0 \mathrm{Ca}$ & $0.0 \mathrm{Ca}$ & $0.0 \mathrm{a}$ & $0.0 \mathrm{Ba}$ & $0.0 \mathrm{Ca}$ \\
\hline \multicolumn{9}{|l|}{$I V E$} \\
\hline Control & 26.1 & 25 & $26.1 \mathrm{Aa}$ & $26.9 \mathrm{Aa}$ & $24.3 \mathrm{Ab}$ & $24.4 \mathrm{Ab}$ & $22.9 \mathrm{Ac}$ & $23.0 \mathrm{Ac}$ \\
\hline \multirow[t]{3}{*}{ Estimate ${ }^{\mathrm{A}}$} & $309 *$ & 35 & $23.6 \mathrm{Aa}$ & $22.5 \mathrm{Bb}$ & $23.4 \mathrm{Aa}$ & $22.2 \mathrm{Ab}$ & $20.9 \mathrm{Ac}$ & $20.9 \mathrm{Ac}$ \\
\hline & & 45 & $25.4 \mathrm{Aa}$ & $24.0 \mathrm{Ab}$ & $26.6 \mathrm{Aa}$ & $23.1 \mathrm{Ac}$ & $20.0 \mathrm{Ad}$ & $20.2 \mathrm{Ad}$ \\
\hline & & 55 & $19.0 \mathrm{Ba}$ & $17.0 \mathrm{Ca}$ & $14.3 \mathrm{Bb}$ & $12.9 \mathrm{Bc}$ & $0.0 \mathrm{Bd}$ & $0.0 \mathrm{Bd}$ \\
\hline $\mathrm{CV}(\%)$ & 7.16 & 65 & $0.0 \mathrm{Ca}$ & $0.0 \mathrm{Da}$ & $0.0 \mathrm{Ca}$ & $0.0 \mathrm{Ca}$ & $0.0 \mathrm{Ba}$ & $0 . \mathrm{Ba}$ \\
\hline \multicolumn{9}{|c|}{ Root length of seedlings $(\mathrm{cm})$} \\
\hline Control & 5.7 & 25 & $6.2 \mathrm{Aa} * *$ & $6.2 \mathrm{Aa}$ & $6.0 \mathrm{Ab}$ & $6.7 \mathrm{Aa}$ & $6.4 \mathrm{Aa}$ & $6.6 \mathrm{Aa}$ \\
\hline \multirow[t]{3}{*}{ Estimate $^{\mathrm{A}}$} & $64 *$ & 35 & $4.8 \mathrm{Ca}$ & $5.0 \mathrm{Ba}$ & $4.6 \mathrm{Bb}$ & $4.0 \mathrm{Bb}$ & $3.7 \mathrm{Cc}$ & $3.9 \mathrm{Bb}$ \\
\hline & & 45 & $5.4 \mathrm{Ba}$ & $4.7 \mathrm{Bb}$ & $4.7 \mathrm{Bb}$ & 4.4 $\mathrm{Bb}$ & $4.1 \mathrm{Bc}$ & $4.0 \mathrm{Bc}$ \\
\hline & & 55 & $4.9 \mathrm{Ca}$ & $4.2 \mathrm{Ba}$ & 4.2 $\mathrm{Ba}$ & $3.9 \mathrm{Bb}$ & $0.0 \mathrm{Dc}$ & $0.0 \mathrm{Cc}$ \\
\hline $\mathrm{CV}(\%)$ & 15.03 & 65 & $0.0 \mathrm{Da}$ & $0.0 \mathrm{Ca}$ & $0.0 \mathrm{Ca}$ & $0.0 \mathrm{Ca}$ & $0.0 \mathrm{Da}$ & $0.0 \mathrm{Ca}$ \\
\hline \multicolumn{9}{|c|}{ Aerial part length of seedlings $(\mathrm{cm})$} \\
\hline Control & 1.4 & 25 & $2.5 \mathrm{Aa}$ & $1.5 \mathrm{Ab}$ & $1.6 \mathrm{Ab}$ & $1.6 \mathrm{Bb}$ & $1.5 \mathrm{Ab}$ & $1.3 \mathrm{Ab}$ \\
\hline \multirow[t]{3}{*}{ Estimate ${ }^{\mathrm{A}}$} & $9.4 *$ & 35 & $1.5 \mathrm{Bb}$ & $1.6 \mathrm{Ab}$ & $1.6 \mathrm{Ab}$ & $2.0 \mathrm{Aa}$ & $1.5 \mathrm{Ab}$ & $1.4 \mathrm{Ab}$ \\
\hline & & 45 & $2.1 \mathrm{Aa}$ & $1.3 \mathrm{Aa}$ & $1.3 \mathrm{Aa}$ & $1.3 \mathrm{Ba}$ & $1.2 \mathrm{Aa}$ & $1.3 \mathrm{Aa}$ \\
\hline & & 55 & $1.3 \mathrm{Ba}$ & $1.7 \mathrm{Aa}$ & $1.1 \mathrm{Ab}$ & $1.1 \mathrm{Bb}$ & $1.0 \mathrm{Ab}$ & $0.0 \mathrm{Bc}$ \\
\hline $\mathrm{CV}(\%)$ & 38.77 & 65 & $0.0 \mathrm{Ca}$ & $0.0 \mathrm{Ba}$ & $0.0 \mathrm{Ba}$ & $0.0 \mathrm{Ca}$ & $0.0 \mathrm{Ba}$ & $0.0 \mathrm{Ba}$ \\
\hline \multicolumn{9}{|c|}{ Root dry mass of seedlings $\left(\mathrm{mg} \mathrm{pl}^{-1}\right)$} \\
\hline Control & 2.3 & 25 & $2.3 \mathrm{Aa}$ & $2.3 \mathrm{Aa}$ & $2.3 \mathrm{Aa}$ & $2.5 \mathrm{Ba}$ & $2.4 \mathrm{Ba}$ & $2.3 \mathrm{Aa}$ \\
\hline \multirow[t]{3}{*}{ Estimate $^{\mathrm{A}}$} & $20.4 *$ & 35 & $2.8 \mathrm{Aa}$ & $2.7 \mathrm{Ab}$ & $2.5 \mathrm{Ab}$ & $3.1 \mathrm{Aa}$ & $2.9 \mathrm{Aa}$ & $2.7 \mathrm{Ab}$ \\
\hline & & 45 & $2.3 \mathrm{Aa}$ & $2.0 \mathrm{Ba}$ & $1.8 \mathrm{Bb}$ & $2.1 \mathrm{Ba}$ & $1.2 \mathrm{Cb}$ & $1.4 \mathrm{Bb}$ \\
\hline & & 55 & $1.9 \mathrm{Ba}$ & $1.1 \mathrm{Ba}$ & $1.3 \mathrm{Ba}$ & $1.3 \mathrm{Ca}$ & $0.0 \mathrm{Db}$ & $0.0 \mathrm{Cb}$ \\
\hline $\mathrm{CV}(\%)$ & 14.99 & 65 & $0.0 \mathrm{Ca}$ & $0.0 \mathrm{Ca}$ & $0.0 \mathrm{Ca}$ & $0.0 \mathrm{Da}$ & $0.0 \mathrm{Da}$ & $0.0 \mathrm{Ca}$ \\
\hline \multicolumn{9}{|c|}{ Dry mass of the aerial part of seedlings ( $\left.m g \mathrm{pl}^{-1}\right)$} \\
\hline Control & 12.9 & 25 & $6.4 \mathrm{Bc}$ & $10.9 \mathrm{Bb}$ & $11.9 \mathrm{Ba}$ & $12.1 \mathrm{Ba}$ & $11.0 \mathrm{Bb}$ & $11.2 \mathrm{Bb}$ \\
\hline \multirow[t]{3}{*}{ Estimate $^{\mathrm{A}}$} & $146 *$ & 35 & $13.3 \mathrm{Ab}$ & $12.1 \mathrm{Ac}$ & $12.3 \mathrm{Ac}$ & 14.7 Aa & $13.3 \mathrm{Ab}$ & $13.5 \mathrm{Ab}$ \\
\hline & & 45 & $12.3 \mathrm{Aa}$ & $12.0 \mathrm{Aa}$ & $11.9 \mathrm{Ba}$ & $10.9 \mathrm{Cb}$ & $9.8 \mathrm{Cc}$ & $8.6 \mathrm{Cc}$ \\
\hline & & 55 & $10.2 \mathrm{Aa}$ & $9.1 \mathrm{Cb}$ & $8.0 \mathrm{Cc}$ & 6.7 Dd & $0.0 \mathrm{De}$ & $0.0 \mathrm{De}$ \\
\hline $\mathrm{CV}(\%)$ & 20.68 & 65 & $0.0 \mathrm{Ca}$ & $0.0 \mathrm{Da}$ & $0.0 \mathrm{Da}$ & $0.0 \mathrm{Ea}$ & $0.0 \mathrm{Da}$ & $0.0 \mathrm{Da}$ \\
\hline
\end{tabular}

Note. * Significant effect by the contrast test of additional treatment (control), versus the factorial (levels of temperature $\times$ periods of time), at $5 \%$ of error level. ${ }^{A}$ Estimate of contrast by coefficients $(+30,-1,-1,-1,-1,-1$, $-1,-1,-1,-1,-1,-1,-1,-1,-1,-1,-1,-1,-1,-1,-1,-1,-1,-1,-1,-1,-1,-1,-1,-1$ and -1) (Ferreira, 2014).** Averages do not followed by the same letter, uppercase in column and lower case in line, differ Scott-Knott test, at $5 \%$ of error level. CV (\%): coefficient of variation.

The development of the safflower seedlings conferred by the tests of length and dry mass of seedlings was negatively affected according to the increase of temperature levels and period of humid heat exposure. The safflower seeds submitted to the thermotherapic treatments at $65^{\circ} \mathrm{C}$, suffered thermal stress which accelerated their deterioration, in a way that prevent the seedling development of these seeds (Table 3). 
Among the safflower seedlings, in general, we observed that the reservations of the seeds germinated were mobilized for the seedling length at 76.7 and $23.3 \%$ for the root and aerial parts, respectively. Yet, the partition of dry mass of safflower seedlings was of 16.4 and $83.6 \%$ for the root and aerial parts, respectively.

We noted that the safflower seedlings have initially greater expansion in the root part, however, with the lower dry mass. Abud et al. (2010) report that the safflower seeds presented germination of the epigeal type and the phanerocotylar seedling, firstly, occurs the protrusion of the root, with greater expansion in volume, and in the sequence the emergence of the cotyledons originating the aerial part.

In Table 3, we presented the coefficients of linear correlation among the total infested seeds in the sanity test and the standard tests of germination and emergence at field. We observed that there was positive correlation among the total infested seeds and the vigor of safflower seeds, highlighting the thermotherapic treatments of $35^{\circ} \mathrm{C} 10$ $\mathrm{mim}^{-1}$ and $45^{\circ} \mathrm{C} 10 \mathrm{mim}^{-1}$, with $13 \%$ of infested seeds (Table 1 ).

The positive correlation that had the greatest highlight for the germination of normal seedlings $(0.96)$ was in the period of zero exposure in water in all the tested temperatures, in these treatments there were $42 \%$ of infested seeds. Yet, the positive correlations for the emergence at field were in the treatments of $45^{\circ} \mathrm{C} 10 \mathrm{mim}^{-1}$ and 55 ${ }^{\circ} \mathrm{C} 10 \mathrm{mim}^{-1}$ (Table 4), these treatments presented total infested seeds of 13 and $12 \%$ respectively.

Table 4. Pearson correlation coefficient between the total infested seeds in sanity test and the first count, germination of normal seedlings, emergence at field and dead seeds in germination test of C. tinctorius submitted to thermotherapy via humid heat

\begin{tabular}{|c|c|c|c|c|c|c|c|c|}
\hline \multirow{3}{*}{\multicolumn{2}{|c|}{ Additional Treatment }} & \multicolumn{7}{|c|}{ Factorial } \\
\hline & & \multirow{2}{*}{$\begin{array}{l}\text { Temperature } \\
\left({ }^{\circ} \mathrm{C}\right)\end{array}$} & \multicolumn{6}{|c|}{ Periods of time (minutes) } \\
\hline & & & 5 & 10 & 15 & 30 & 45 & 60 \\
\hline \multicolumn{9}{|c|}{ First count of germination (vigor) } \\
\hline \multirow[t]{5}{*}{ Control } & $0.43^{* *}$ & 25 & -0.76 & -0.39 & -0.66 & -0.3 & $0.42 * *$ & -0.43 \\
\hline & & 35 & $0.65^{* *}$ & $0.93 * *$ & -0.72 & -0.52 & $0.86^{* *}$ & -0.5 \\
\hline & & 45 & $0.30 * *$ & $0.76^{* *}$ & -0.16 & -0.33 & -0.99 & -0.48 \\
\hline & & 55 & 0 & -0.96 & -0.65 & 0 & 0 & 0 \\
\hline & & 65 & 0 & 0 & 0 & 0 & 0 & 0 \\
\hline \multicolumn{9}{|c|}{ Germination of normal seedlings } \\
\hline \multirow[t]{5}{*}{ Control } & $0.96^{* *}$ & 25 & -0.63 & -0.8 & -0.28 & $0.90 * *$ & $0.17 * *$ & -0.85 \\
\hline & & 35 & -0.41 & $0.50 * *$ & -0.76 & -0.47 & -0.07 & -0.85 \\
\hline & & 45 & -0.63 & -0.17 & $0.66 * *$ & $0.58 * *$ & -0.14 & -0.88 \\
\hline & & 55 & 0.04 & 0.06 & -0.31 & -0.49 & 0 & 0 \\
\hline & & 65 & 0 & 0 & 0 & 0 & 0 & 0 \\
\hline \multicolumn{9}{|c|}{ Emergence at field } \\
\hline \multirow[t]{5}{*}{ Control } & -0.02 & 25 & $0.22 * *$ & 0.08 & -0.76 & $0.48 * *$ & $0.69 * *$ & $0.58 * *$ \\
\hline & & 35 & $0.22 * *$ & -0.05 & -0.76 & $0.49 * *$ & $0.69 * *$ & $0.58 * *$ \\
\hline & & 45 & -0.52 & $0.84 * *$ & -0.13 & -0.82 & $0.14 * *$ & $0.29 * *$ \\
\hline & & 55 & -0.52 & $0.84 * *$ & -0.13 & -0.82 & 0 & 0 \\
\hline & & 65 & 0 & 0 & 0 & 0 & 0 & 0 \\
\hline \multicolumn{9}{|c|}{ Dead seeds in germination test } \\
\hline \multirow[t]{5}{*}{ Control } & -0.23 & 25 & $0.22 * *$ & $0.35^{* *}$ & $0.33 * *$ & $0.67 * *$ & $0.87 * *$ & 0 \\
\hline & & 35 & $0.36^{* *}$ & -0.54 & $0.85 * *$ & $0.40 * *$ & $0.24 * *$ & $0.24 * *$ \\
\hline & & 45 & $0.60 * *$ & -0.68 & -0.31 & -0.44 & $0.11 *$ & $0.73 * *$ \\
\hline & & 55 & -0.43 & $0.27 * *$ & $0.32 * *$ & $0.82 * *$ & $0.99 * *$ & -0.48 \\
\hline & & 65 & $0.73 * *$ & -0.58 & $0.18^{* *}$ & -0.13 & $0.37 * *$ & $0.54 * *$ \\
\hline
\end{tabular}

Note. ${ }^{*}$ and $*$ are significant by $t$ test in 0.01 and 0.05 of error probability, respectively.

The positive correlations of the dead safflower seeds in the germination test were distinct in virtue of the high variation of infested seeds. In general, we determined that the greater the incidence of phytopathogens, the more the vigor, the germination of normal seedlings and the emergence at field were negatively affected. Härter et al. 
(2014) report the importance of exemption of phytopathogens in the seeds, because the contamination of the same can cause damage in the future development of the seedlings at the field.

In general, the relation to sanity of safflower seeds after the submission to thermotherapy via humid heat, we observed efficiency in the percentage control of phytopathogens in all the tested temperatures and periods of time. However, this thermotherapic technique preserves the physiological quality of the safflower seeds until the temperature of $45^{\circ} \mathrm{C}$.

Among the variation of the thermotherapic treatments tested on the safflower seeds, we highlight the treatment at $45{ }^{\circ} \mathrm{C}, 15 \mathrm{~min}^{-1}$, because it promotes the improvement in the physiological expression of the same in vigor (40\%), germination (75\%) and emergence at field (83\%), besides the control on the total infested seeds $(5 \%)$.

Despite the emphasis and the international investment, the safflower cultivation in Brazil is incipient. Initial research on crop improvement and adaptability indicate the species as an alternative to off-season cultivation, especially for seed production. Results of the study suggest good prospects for the use of thermotherapy via humid heat for the treatment of safflower seeds, offering an option to the use of chemical products. Due to the fact of the low environmental impact, without residual effect and efficiency to phytosanitary control, beyond the easy handling of the method, appropriate for its use in familiar or agroecological agriculture.

\section{Conclusion}

The treatment of seeds by means of thermotherapy via humid heat was efficient for the control of incident phytopathogens in safflower seeds, without damage to the physiological quality. Among the treatments of thermotherapy of seeds, the combination of $45^{\circ} \mathrm{C}, 15 \mathrm{~min}^{-1}$ provided better phytosanitary quality for safflower seeds, incrementing also its potential of germination and emergence at field.

\section{Acknowledgements}

We thank CAPES (Coordenação de Aperfeiçoamento de Pessoal de Nível Superior) by the incentive and funding of this work, and the Postgraduate Program in Agronomy of Federal University of Santa Maria.

\section{References}

Abud, H. F., Gonçalves, N. G., Reis, R. G. E. S., Gallão, M. I., \& Innecco, R. (2010). Morfologia de sementes e plântulas de cártamos. Revista Ciência Agronômica, 41(2), 259-265. https://doi.org/10.1590/S1806-6690 2010000200013

Braga, M. P., Olinda, R. A., Homma, S. K., \& Dias, C. T. S. (2010). Relações entre tratamento térmico, germinação, vigor e sanidade de sementes de tomate. Revista Brasileira de Sementes, 32(1), 101-110. https://doi.org/10.1590/S0101-31222010000100012

Brasil, Ministério da Agricultura, Pecuária e Abastecimento. (2009a). Regras para análise de sementes. Secretaria de Defesa Agropecuária. Brasília: MAPA/ACS.

Brasil, Ministério da Agricultura, Pecuária e Abastecimento. (2009b). Manual de Análise Sanitária de Sementes. Secretaria de Defesa Agropecuária. Brasília: MAPA/ACS.

Brasil, Ministério da Agricultura, Pecuária e Abastecimento. (2013). Instrução Normativa n. 45. Secretaria de Defesa Agropecuária. Brasília: MAPA/ACS.

Brito, C. H., Costa, N. P., Batista, J. L., Nascimento, L., Oliveira, H. D., \& Barreto, E. S. (2008). Termoterapia para o controle de patógenos em pós-colheita emfrutos da cajazeira. Acta Science Agronômica, 30(1), 19-23. https://doi.org/10.4025/actasciagron.v30i1.1117

Carmo, M. G. F., Correa, F. M., Cordeiro, E. S., Carvalho, A. O., \& Rossetto, C. A. V. (2004). Tratamentos de erradicação de Xanthomonas vesicatoria e efeitos sobre a qualidade das sementes de tomate. Horticultura Brasileira, 22(3), 579-584. https://doi.org/10.1590/S0102-05362004000300015

Coutinho, W. M., Mann, R. S., Vieira, M. G. G. C., Machado, C. F., \& Machado, J. (2007). Qualidade sanitária e fisiológica de sementes de milho submetidas à termoterapia e condicionamento fisiológico. Fitopatologia Brasileira, 32(6), 458-4654. https://doi.org/10.1590/S0100-41582007000600002

Cunha, R. P., Carvalj, I. L., Olsen, D., Vieiria, J. F., Soares, V. N., \& Tunes, L. M. (2017). Termoterapia no controle de patógenos associados às sementes de abóbora. Tecnologia \& Ciência Agropecuária, 11(2), 53-57.

Emongor, V., \& Oagile, O. (2017). Safflower production. Botswana: The Regional Universities Forum for Capacity Building in Agriculture-RUFORUM. 
Estefani, R. C. C., Miranda Filho, E. J., \& Uesugi, C. H. (2007). Tratamentos térmico e químico de sementes de feijoeiro: eficiência na erradicação de Curtobacterium flaccumfaciens pv. flaccumfaciens e efeitos na qualidade fisiológica das sementes. Fitopatologia Brasileira, 32(1), 434-438. https://doi.org/10.1590/ S0100-41582007000500011

FAOSTAT. (2017). Crops: Safflower. Food and Agriculture Organization of the United Nations Statistics Division. Retrieved March 2, 2018, from http://faostat3.fao.org/browse/Q/QC/E

Ferreira, D. F. (2014). Sisvar: A guide for its bootstrap procedures in multiple comparisons. Ciência e Agrotecnologia, 38(2), 109-112. https://doi.org/10.1590/S1413-70542014000200001

Girardi, L., Bellé, R. A., Michelon, S. Giradi, B. A., \&Muniz, M. F. B. (2013). Qualidade de sementes de cártamo colhidas em diferentes períodos de maturação. Revista Acadêmica de Ciências Agrárias e Ambiental, 11(1), S67-S73. https://doi.org/10.7213/academica.10.S01.AO08

Harter, L. S. H., Hartes, F. D., Deuner, C. Meneghello, G. E., \& Villela, F. (2014). Salinidade e desempenho fisiológico de sementes e plântulas de mogango. Horticultura Brasileira, 32(1), 80-85. https://doi.org/ $10.1590 / \mathrm{S} 0102-05362014000100013$

Lazarotto, M., Mezzomo, R., Maciel, C. G., Bovolini, M, P., \& Muniz, M. F. B. (2013). Tratamento de sementes de canafístula via calor úmido. Revista Ciência Agraria, 56(3), 268-273. https://doi.org/10.4322/ rca.2013.038

Machado, J. C. (2000). Tratamento de sementes no controle de doenças. Lavras: UFLA.

Maguire, J. D. (1962). Speed of germination aid in selection and evaluation for seedling emergence and vigor. Crop Science, 2(2), 176-177. https://doi.org/10.2135/cropsci1962.0011183X000200020033x

Marchi, C. E., Fernandes, C. D., Ananche, F. C., Jerba, V. F., \& Fabris, L. R. (2008). Quimio e termoterapia em sementes e aplicação de fungicidas em Brachiaria brizantha como estratégias no manejo do carvão. Summa Phytopathol, 34(4), 321-325. https://doi.org/10.1590/S0100-54052008000400004

Marcos-Filho, J. (2015). Fisiologia de sementes de plantas cultivadas. ABRATES: Londrina.

Marostega, T. N., Cuiabano, M. N., Ranzani, R. E., Luz, P. B., \& Sobrino, S. P. (2015). Efeito de tratamento térmico na superação de dormência de sementes de Passiflora suberosa L. Bioscience Journal, 31(2), 445-450. https://doi.org/10.14393/BJ-v31n2a2015-22385

Mendes, M. A. S., Lima, P. M. M. P., Fonseca, J. N. L., \& Santos, M. F. (2011). Erradicação de Fusarium oxysporum em sementes de alfafa utilizando termo e quimioterapia. Fitopatologia Brasileira, 26(2), 148-152. https://doi.org/10.1590/S0100-41582001000200005

Nakagawa, J. (1999). Testes de vigor baseados na avaliação das plântulas. In F. C. Kryzanowski, R. D. Vieira, \& J. B. França Neto (Eds.), Vigor de sementes: Conceitos e testes. Londrina: ABRATES.

Oliveira, M. D. M., Nascimento, L. C., Alves, E. U., Gonçalves, E. P., Guedes, R. S., Silva Neto, J. J. (2011). Qualidade sanitária e fisiológica de sementes de Amburana cearenses A.C. Smith submetidas à termoterapia e tratamento químico. Acta Scientiarum. Agronomy, 33(1), 45-50. https://doi.org/10.4025/ actasciagron.v33i1.5645

Schneider, C. F., Gusatto, F. C., Malavasi, M. M., Stangarlin, J. R., \& Malavasi, U, C. (2015). Termoterapia na qualidade fisiológica e sanitária de sementes armazenadas de pinhão-manso. Semina: Ciências Agrárias, 36(1), 47-56. https://doi.org/10.5433/1679-0359.2015v36n1p47

Silva, A. M. S., Carmo, M. G. F., Olivares, F. L., \& Pereira, A. J. (2002). Termoterapia via calor seco no tratamento de sementes de tomate: Eficiência na erradicação de Xanthomonas campestris pv. Vesicatoria e efeitos sobre a semente. Fitopatologia Brasileira, 27(6), 586-593. https://doi.org/10.1590/S0100-41582 002000600005

\section{Copyrights}

Copyright for this article is retained by the author(s), with first publication rights granted to the journal.

This is an open-access article distributed under the terms and conditions of the Creative Commons Attribution license (http://creativecommons.org/licenses/by/4.0/). 